\title{
Perancangan Motif Batik dari Potensi Daerah Kabupaten Sidoarjo sebagai Cara Melestarikan dan Memperkaya Motif Batik Sidoarjo
}

\author{
Shanastra Nautica dan Sayatman \\ Departemen Desain Komunikasi Visual, Fakultas Arsitektur Desain dan Perencanaan, \\ Institut Teknologi Sepuluh Nopember (ITS) \\ e-mail: sayatasik@gmail.com
}

\begin{abstract}
Abstrak-Konsep Desain pada perancangan ini adalah "The New Batik by the strength of Sidoarjo". Makna dari keywords tersebut dalah membuat desain motif batik baru yang berasal dari kekuatan dari Sidoarjo. Kekuatan tersebut berasal dari potensi daerah Sidoarjo. Perancangan ini mengkaji tentang merancang desain batik baru dari potensi daerah Sidoarjo yang dapat menjadi kekuatan dari Sidoarjo. Ragam motif baru batik Sidoarjo ini adalah salah satu cara melestarikan dan memperkaya motif batik kabupaten Sidoarjo dan sebagai referensi para pengerajin batik Sidoarjo untuk berinovasi dan bereksperimen dalam mendesain batik. Sehingga banyak sekali potensi dari kabupaten sidoarjo yang menjadi kekuatan dari Sidoarjo yang dapat diolah menjadi motif batik.
\end{abstract}

Kata Kunci-Potensi, Desain Motif, Batik, Sidoarjo

\section{PENDAHULUAN}

$\mathrm{S}_{\mathrm{b}}^{\mathrm{E}}$ ELAMA ini warga Sidoarjo yang menekuni kerajinan batik hanya lebih mementingkan segi bisnis belaka. Mereka kurang memperhatikan ciri khas yang harus dipertahankan sebagai warisan budaya. Selain itu Banyak juga motif batik asli Sidoarjo yang dijiplak pengerajin batik dari daerah lain. Karena itu, pengerajin batik dan Pemkab Sidoarjo berupaya mematenkan jenis batik asli Sidoarjo. Ibu Dyah Setyowati selaku budayawan dan juga seniman Sidoarjo berpendapat, "Mungkin yang akan kami patenkan ada lima jenis dulu di Balai Batik Tradisional Yogyakarta. Sebab, kelima jenis batik itu sudah lolos seleksi. supaya mudah dikenal masyarakat luas." Ditambah lagi, menurut Pak Nanang pengerajin batik Jetis Sidoarjo, motif yang memiliki kekhasan Sidoarjo masih sama yang dulu seperti Sekardangan, Cipretan, dan lainnya itupun kalau ada yang pesan, dan di kampung Jetis kebanyakan membuat motif sendiri dan terkadang hanya membuat tidak memberi makna dan cerita. Selain itu banyak warga Sidoarjo yang menekuni kerajinan batik lebih mementingkan dari segi bisnis. Dan juga pemkab Sidoarjo berupaya mematenkan batik asli Sidoarjo. Hal tersebutlah dapat diangkat dari potensi kabupaten Sidoarjo seperti pada Gambar 1.

Dengan terjabarnya potensi-porensi diatas, penulis menyebar kuisioner untuk menentukan potensi daerah kabupaten Sidoarjo yang populer dikalangan masyarakat dan dari kuisioner tersebut pula penulis menentukan pola kain batik yang akan dibuat seperti baju, jarik, sarung, dan selendang. Bukti pemilihan potensi daerah yang popular ditunjukkan pada Gambar 2.

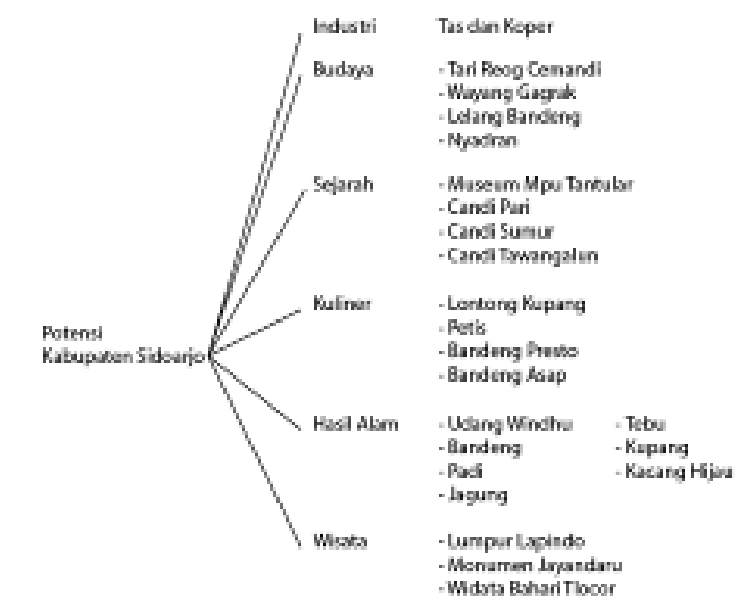

Gambar 1. Potensi Kabupaten Sidoarjo. Sumber : Nautica, 2019

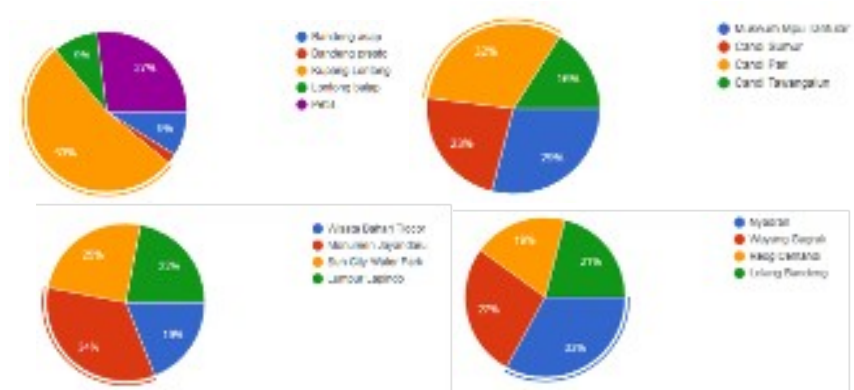

Gambar 2. (a) potensi daerah tempat bersejarah, (b) potensi daerah kuiner, (c) potensi daerah tempat wisata, dan (d) potensi daerah budaya Sumber : Nautica, 2019

Dari hasil kuisioner diatas terlihat potensi daerah yang populer seperti candi Pari pada potensi daerah tempat bersejarah, monumen Jayandaru pada potensi daerah tempat wisata, kupan lontong pada potensi daerah kuliner, Nyadran dan Wayang Gagrak pada potensi daerah budaya. Dalam penentuan pola batik yang akan dibuat dalam selembar kain dari hasil kuisioner menjawab kain sarung dan jarik.

Maka dari itu, untuk memicu perkembangan motif batik, dan memberikan acuan pada pengerajin batik supaya tidak mementingkan dari segi bisnis, dan membantu Pemkab Sidoarjo untuk mempatenkan batik asli Sidoarjo dari segi motifnya. Hasil luaran yang akan dihasilkan dari penelitian berupa desain motif batik yang didalamnya terdapat unsur visual dari potensi kabupaten Sidoarjo. Hal ini bertujuan untuk menghasilkan sebuah motif baru, yang nantinya desain 
motif batik ini akan diaplikasikan langsung pada kain berukuran A3 $(29.7 \mathrm{~cm} \times 42 \mathrm{~cm})$ sebanyak 2 lembar kain setiap 1 motif baru tentang potensi tersebut, dengan perbandinggan gambar 1:1 sehingga dapat menampilkan kedetailan dari sebuah motif batik Sidoarjo.

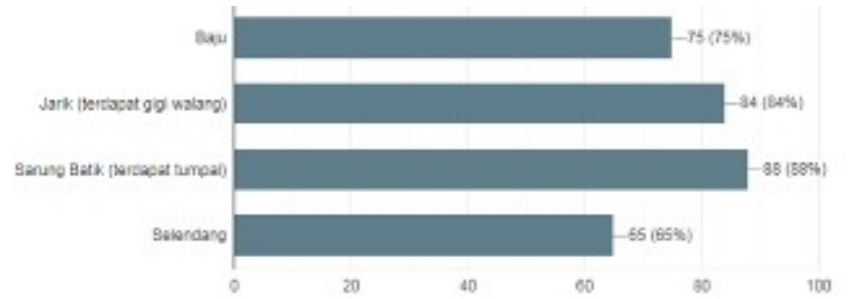

Gambar 3. Hasil kuisioner batik yang dimiliki responden.

Sumber: Nautica, 2019

\section{A. Rumusan Masalah}

Berdasarkan identifikasi masalah diatas, maka mucul sebuah rumusan masalah sebagai berikut: "Bagaimana memvisualisasikan potensi daerah populer kabupaten Sidoarjo menjadi sebuah batik dalam pola Jarik dan Sarung?"

\section{B. Batasan Masalah}

Masalah-masalah yang akan diselesaikan dalam penelitian ini akan dibatasi sebagai berikut:

1. Pada perancangan ini penulis hanya akan menyelesaikan masalah yang berhubungan dengan desain yang dikaji menurut teori dan ilmu Desain Komunikasi Visual yaitu memvisualisasikan potensi daerah yang populer kabupaten Sidoarjo dalam menciptakan motif batik Sidoarjo sebanyak 10 motif.

2. Perancangan ini hanya akan membuat motif baru yang berkaitan dengan kabupaten Sidoarjo, batik sarung, dan potensi kabupaten Sidoarjo.

3. Studi penelitian untuk perancangan dibataskan pada lingkup Sidoarjo

4. Perancangan selembar motif batik pada pola sarung batik dan jarik

5. Potensi yang diambil dari kesimpulan hasil kuisioner (Monumen Jayandaru, Candi Pari, kupang Lontong, wayang Gagrak, dan Nyadran).

6. Kain batik dengan pola jarik dan sarung dengan motif stilasi dari memvisualisasikan potensi daerah populer kabupaten Sidoarjo.

\section{Tujuan}

Dengan dibuatnya motif batik baru dari kampung Jetis diharapkan tujuan pembuatan dapat tersampaikan dengan

baik, seperti :

1. Salah satu cara melestarikan budaya Sidoarjo.

2. Memperkenalkan motif Sidoarjo.

3. Memperkuat karakter dan ciri khas kabupaten Sidoarjo dari produk Batik Sidoarjo.

4. Menginspirasi dan menstimulasi pengerajin batik Jetis untuk menciptakan motif dengan mengekplorasi potensi-potensi yang ada di kabupaten Sidoarjo.

5. Meningkatkan perekonomian daerah melalui pengembangan sentra industri batik Sidoarjo.

6. Menciptakan motif baru yang dapat dijadikan sebagai bahan belajar pengembangan motif batik dan pendokumentasian batik tulis Sidoarjo.

\section{Manfaat Perancangan}

\section{Manfaat Teoritis}

Secara teoritis bahwa perancangan motif batik sebagai media melestarikan seni dan budaya batik di kabupaten Sidoarjo dapat memperkaya keilmuan DKV dalam aspekaspek bagaimana merancang sebuah selembar kain sarung batik yang meliputi stilasi, warna yang digunakan pada batik Sidoarjo, serta mengeksplorasi potensi kabupaten Sidoarjo untuk menjadi motif baru batik Sidoarjo.

2. Manfaat Praktis

Sedangkan secara praktis bahwa perancangan motif batik Sidoarjo ini dapat menjadi sebuah inspirasi bagi mahasiswa, ahli sejarah dan masyarakat luas yang ingin mengetahui cara mengeksplorasi sebuah motif batik lebih dalam. Selain itu Perancangan motif batik baru ini dapat menjadi sebuah stimulus bagi para pengusaha dan pengerajin batik tulis Jetis Sidoarjo bagaimana mereka dapat mengeksplorasi motif batik dari potensi yang ada di kabupaten Sidoarjo. Serta pada perancangan ini dapat membantu pemerintah dalam memperkenalkan potensi daerah dan data yang rinci terkait tentang motif batik Sidoarjo sebagai bahan penelitian.

\section{II.KAJIAN PUSTAKA}

\section{A. Teknik Pembuatan Batik}

Menurut buku yang berjudul "Warisan Adiluhung Nusantara", teknik dalam pembuatan batik dapat digolongkan menjadi 3 macam teknik, yaitu: [1]

\section{Batik Tulis}

Teknik membatik yang pengerjaannya menggunakan alat yang bernama canting dengan bahan dasar kuningan, berfungsi untuk menampung malam/lilin panas yang dugunakan untuk melukiskan ragam motif diatas kain. Teknik batik tulis ini memiliki karakter yang mewah, luwes, dan memiliki estetika yang tinggi karena disetiap goresan yang diaplikasikan akan menghasilkan goresan yang berbedabeda karena murni digambar dengan tangan oleh pengerajin batik, sehingga membutuhkan waktu yang lama dalam pengerjaannya untuk menjadikan hasil yang bagus dan unik.

\section{Batik Cap}

Teknik membatik yang menggunakan alat bernama canting cap yang terbuat dari tembaga yang sudah dibentuk sesuai motif batik untuk menghias kain. Canting cap berfungsi sama dengan stempel besar yang dibubuhkan malam/lilin yang kemudian dicapkan diatas kain. Pada proses produksinya batik cap ini pengerajin batik dapat menghemat tenaga karena tidak perlu menggambar pola/desain diatas kain diatas kain secara manual yang seperti batik tulis.

\section{Batik Semi Tulis (Tulis dan Cap)}

Teknik membatik yang memadukan teknik cap dan teknik tulis, yang dimana motif batik digambar dengan cara di cap dengan canting cap diatas kain, setelah itu untuk keperluan pewarnaan maka sebagian motig yang akan diberi warna berbeda ditutup dengan malam/lilin menggunakan canting tulis.

\section{B. Struktur Dasar Batik}

Struktur atau dasar penyusunan batik merupakan struktur dasar batik. Struktur dasar batik terdiri dari beberapa unsure pola atau motif batik yang tersusun berdasarkan motif batik yang sudah baku. Struktur dasar batik itu terdiri dari [2]. 
1. Motif Utama, Merupakan unsure pokok motif, berupa gambar-gambar bentuk tertentu, karena merupakan unsure pokok maka disebut motif ornamen utama.

2. Motif Pengisi, Merupakan motif yang berupa gambargambar yang dibuat untuk mengisi bidang, bentuknya lebih kecil dan tidak turut membentuk arti atau jiwa motif tersebut yang disebut ornamen selingan (pengisi).

3. Isen, Merupakan motif yang digunakan untuk memperindah secara keseluruhan baik ornamen pokok ataupun ornamen pengisi diberi isian berupa: titik-titik, garis-garis, gabungan garis dan titik, dan biasanya isen tersebut dalam seni membatik mempunyai nama, dan bentuk tertentu, dan jumlanya banyak.

\section{Komponen Batik}

Dalam pembuatan batik, ada 3 komponen utama, yaitu: warna, garis, dan gaya gambar. Ketiga komponen utama inilah yang dapat membentuk batik menjadi tampilan kain yang indah dan menarik [1].

1. Warna, dapat memberikan kesan dan identitas tertentu sesesuai dengan kondisi social dan pengamatnya. Masyarakat dengan penganut warna memiliki pandangan dan pemikiran yang berbeda-beda terhadap warna.

2. Garis, merupakan goresan di atas permukaan benda atau bidang gambar. Garis-garis inilah yang dapat membentuk corak dan motif batik sehingga menjadi gambar yang indah sesuai dengan yang diinginkan dan menjadi panduan dalam penggambaran dalam membatik.

3. Gaya Gambar, untuk suatu batik, pada umumnya memakai gaya gambar stilasi dengan teknik merengga. Stilasi merupakan menyederhanakan bentuk obyek asli dengan penggayaan yang bersifat dekoratif namun ciri khas tersebut mampu menjnjukkan bentuk aslinya. Sedangkan merengga merupakan pemberian gambar pada permukaan gambar suatu obyek seperti tumbuhan, hewan, atau bentukan geometri lainnya, dan pada umumnya teknik merengga digunakan untuk menciptakan motif-motif pada tekstil termasuk batik.

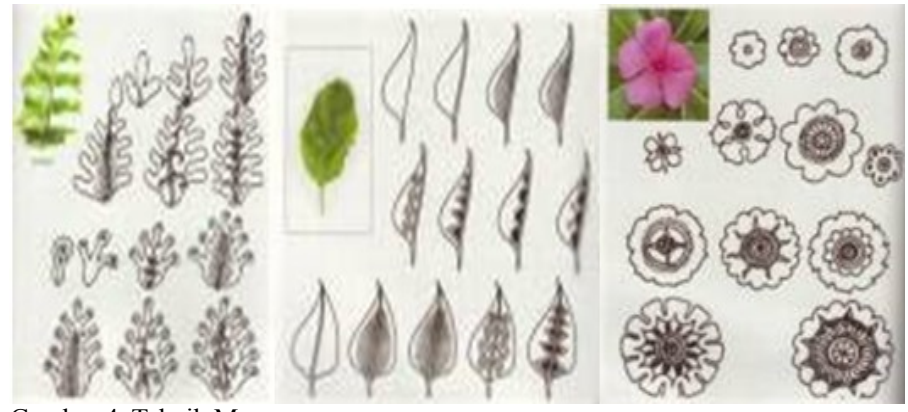

Gambar 4. Teknik Merengga.

Sumber: https://sekolahsenibudaya.wordpress.com/2016/11/03/dasar-dasarmenggambar-motif-batik/

\section{Elememen Visual}

Desain grafis, desain interior, fashion merupakan salah tiga dari industri kreatif yang menggunakan Prang color wheel sebagai panduan sebelum menerapkan warna yang akan digunakan, hal tersebut untuk menyatukan keseimbangan dan hamonisasi untuk menciptakan tampilan yang lebih menarik dan dapat dinikmati yang berkaitan dengan pemahaman teori warna secara psikis. Dalam busana memiliki 3 penerapan yang berbeda, seperti sebagai berikut [3]:

1. Monochromatic Color, warna yang dihasilkan melalui gradasi warna yang dipilih terhadap terhadap warna gelap ataupun warna terang dari warna tersebut. Dapat dikatakan warna Monochromatic merupakan warna yang lebih 'aman' karena dapat terhindar dari kesalahan dalam pemilihan warna dan mempermudah dalam pemilihan komposisi warna. Seperti halnya satu warna yang sama, namu memliki perbedalaan dalam turunan warna (tints tones shades).

2. Accent Color, penambahan warna yang berbeda dari paduan warna yang tersedia, namun warna tersebut tetap dapat dinikmati. Jadi accent color tersebut ditentukan setelah melihat warna yang dominan yang digunakan.

3. Neutral Color, warna tersebut adalah putih, hitam, abuabu, coklat, silver dan gold. Warna tersebut tidak akan pernah salah jika dikombinasikan dengan warna dalam color wheel, dikarenakan warna tersebut tidak dap dianggap sebagai warna utama dalam padupadan busana. Neutral color dapat berdiri sendiri dengan penerapan warna Monochromatic, sehingga dapatterlihat harmonis.

\section{METODOLOGI DESAIN}

\section{A. Sumber Data Penelitian}

Sumber data didapat oleh peneliti untuk merancang sebuah Buku Visual Ragam Motif Batik Jetis Sidoarjo.

1. Observasi, Penelitian dilakukakan di kampung Jetis Sidoarjo, hal itu dilakukan untuk mendapatkan data tentang sikap dan kehidupan saat ini dari kampung Jetis Sidoarjo.

2. Depth interview, Wawancara mendalam ini dilakukan dengan pengerajin batik, pemilik usaha batik, budayaawan, dan praktisi sebagai salah satu data untuk mengidentifikasi permasalahan. Wawancara mendalam dilakukan juga kepada saksi sejarah untuk mendapatkan data otentik tentang sejarah disetiap pembuatan motif batik, yang nantinya dapat dijadikan konten dalam perancarang buku visual ragam motif batik Jetis Sidoarjo.

3. Dokumentasi Foto, Pendokumentasian foto untuk membuat konten buku yang nantinya akan ditampilkan beragam motif batik Jetis Sidoarjo. Selain itu dokumentasi foto ini juga dapat memperkaya sumber data dan membuat lebih akurat.

4. Studi literatur, Studi literatur dilakukan untuk mengumpulkan berbagai data dan informasi tentang batik Sidoarjo, serta untuk mendapatkan data tentang cara membuat buku sehingga peneliti dapat memperkaya konten buku visual batik Jetis Sidoarjo dan bagaimana merancang sebuah buku yang menarik dan informatif.

5. Studi eksisting, biasa disebut penelitian sebelumnya, dijadikan sebagai acuan dalam merancang buku visual ragam motif batik Jetis Sidoarjo. Peneliti melakukan studi eksistiing yntuk menganalisa dan membuat tolak ukur untuk pembuatan buku visual tentang ragam motif batik Jetis Sidoarjo. 
6. Riset Eksperimental, Mengujikan hasil Desain Batik yang telah dibuat kepada para pengerajin batik di Jetis Sidoarjo dan budayawan yang memngerti/memahami tentang ciri khas/karakteristik kebudayaan Sidoarjo.

7. User testing, Pengambilan data dari hasil User Testing merupakan suatu proses pengujian dari pembaca yang bertujuan untuk menghasilkan dokumen yang dapat dijadikan sebuak bukti jika perancangan buku visual ragam motif batik Jetis Sidoarjo dapat diterima.

\section{B. Prototyping}

Untuk merancang sebuah motif batik, peneliti harus menyiapkan desain motif dari potensi daaerah kabupaten Sidoarjo yang nantinya akan di batik pada kain.

\section{Teknik Sampling}

Dengan tujuan supaya pada perancangan ini mempunyai target dan konsep yang baik dan tepat dengan mempertimbangkan kebutuhan, selera, dan minat dari target audiens.

\section{Populasi}

1. Segmentasi Demografis
a. Jenis Kelamin : Laki-laki dan Perempuan
b. Usia : 35-50 tahun
c. Pemasukan : > Rp 5000.000,00
d. Pekerjaan : Pengusaha, pengerajin batik, dan desainer batik

2. Segmentasi Geografis

Target audiens dari perancangan budayawan, seniman, atau pecinta kain batik yang berdomisili di kota Sidoarjo di kampung Jetis.

3. Segmentasi Psikografis
a. Memiliki minat dengan batik dari daerah
b. Memiliki rasa ingin tahu dan minta dalam belajar
c. Memiliki ketertarikan dan minat terhadap batik, seni, dan budaya
d. Tertarik untuk melestarikan dan mengoleksi kearifan lokal dan budaya daerah

\section{KONSEP DESAIN}

Konsep dari perancangan perancangan motif batik dari potensi daerah Sidoarjo ini merupakan membuat stilasi dari 5 potensi daerah yang telah dipilih seperti monumen Jayandaru yang berasal dari hasil bumi dari kabupaten Sidoarjo udang windhu dan ikan bandeng, kedua dari candi Pari peninggalan bersejarah di daerah Porong, ketiga merupakan salah satu kesenian yang masih ada di Sidoarjo yaitu wayang gagrak Jawatimuaran, keempat merupakan salah satu kuliner yang populer di Sidoarjo yaitu Lontong Kupang. Dan ke yang kelima adalah salah satu tradisi di kabupaten Sidoarjo yang biasa disebut dengan Nyadran.

Dengan dibuatkan nya motif batik yang mencirikan dari potensi daerah kabupaten Sidoarjo diharapkan nantinya dapat menjadi sarana referansi dan edukasi para pengerajin batik di Sidoarjo supaya dapat terinspirasi untuk menciptakan motif batik Sidoarjo dan terciptanya ragam motif baru tersebut diharapkan dapat meningkatkan minat masyarakat pada motif batik Sidoarjo dan memperkaya motif batik Sidoarjo saat ini.

Berikut merupakan bagan konsep desain motif batik dari potensi daerah kabupaten Sidoarjo :

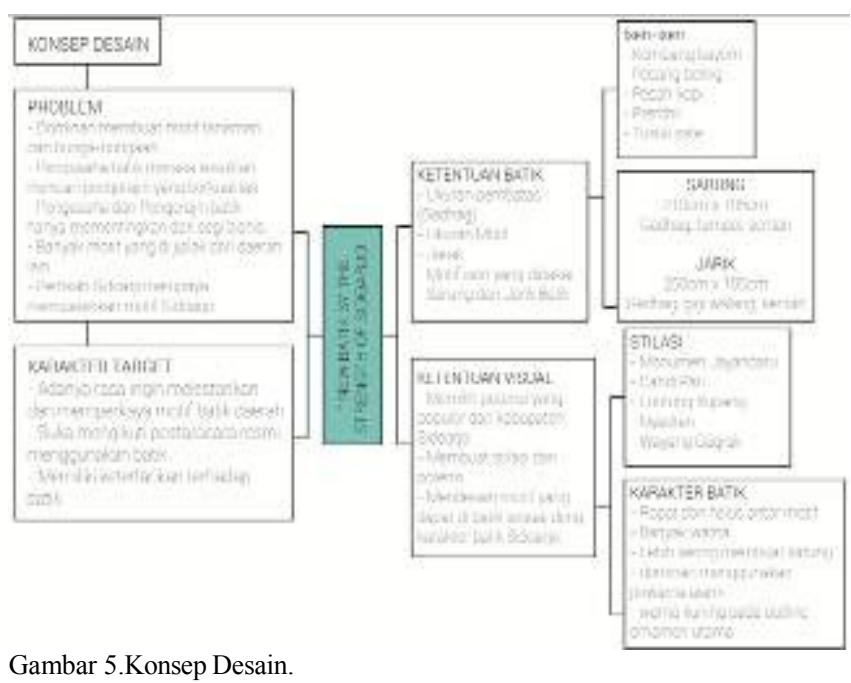

Sumber : Nautica, 2018

\section{A. Keywords Konsep Desain}

Pada perancangan ini penulis menggunakan konsep desain "The New Batik by the strength of Sidoarjo" yang mendeskripsikan dari sebuah kekuatan dari kabupaten Sidoarjo. Hal tersebut yang nantikan akan mendukung dalam pembuatan motif batik Sidoarjo.

Penulis memabawa permasalahan seperti dominannya motif batik yang dibuat dari tumbuhan atau bunga-bungaan. Sayangnya sedikitny motif yang dibuat dari kekuatan dari Sidoarjo. Kekuatan dari Sidoarjo antaralain Monumen Jayandaru, Candi Pari, Lontong Kupang, Wayang Gagrak, Nyadran dan lain sebagainya.

\section{B. Kriteria Desain}

Pada proses perancangan ini terdapataspek yang akandidesain dalam pembuatan motif batik. Berikut merupakan rincian aspek tersebut :

\section{Gaya Gambar}

Pada gaya gambar yang digunakan pada perancangan eksplorasi motif batik ini menggunakan teknik stilasi dengan menyederhanakan sesuatu tanpa merubah bentuk aslinya.

\section{Isen-isen}

Kriteria pada Batik Sidoarjo memiliki kriteria sebagai berikut:

1. Tidak banyak ruang kosong

2. Isen rapat tidak terlalu ranggang

3. Jenis isen biasa menggunakan pecah kopi, tusuk sate, kembang bayem, pecah beling, seritan, Prenthil.

\section{E. Komponen Motif}

Terdapat beberapa komponen dalam pembuatan motif batik seperti :

1. Ornamen Utama, Kriteria pada ornamen utama yang akan diaplikasikan mencakup ornamen yang bersifat dominan, berukuran lebih besar.

2. Ornamen Tambahan, bersifat mendukung ornamen utama biasanya berbentuk floral.

3. Isen-isen, memiliki ukuran yang lebih kecil dan biasa diletakkan sebagai background untuk mengisi ruang kosong pada bidang. 
4. Warna, penentuan warna pada pembuatan motif ini menggunakan perpaduan warna alami dan kimia. Berikut merupakan palet warna yang akan digunakan dalam pembuatan motif batik Sidoarjo:

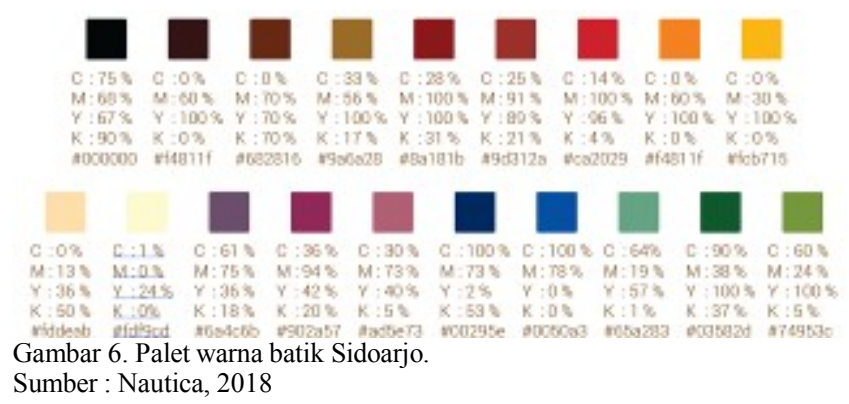

\section{E. Monumen Jayandaru}

Monumen Jayandaru merupakan sebuah icon Sidoarjo, yaitu udang dan bandeng. Udang dan bendeng merupakan hasil tambak yang melimpah dari kabupaten Sidoarjo. Jayandaru memiliki arti kekayaan. Nama tersebut diambil dari nama buah pohon Jatiwasesa yang memiliki bunga dengan nama Dewandaru.

\section{F. Candi Pari}

Candi Peri merupakan salah satu candi yang populer di kabupaten sidoarjo yang terletak di kecamatan Porong, yang didirikan pada tahun 1293 Saka (1371M). Candi ini didirikan pada masa Majapahit ketika di bawah perintahan Raja Hayam Wuruk.

\section{G. Lontong Kupang}

Lontong Kupang merupakan salah satu makanan khas Sidoarjo. Makanan satu ini berasal dari hewan bernama kupang sejenis dengan kerang-kerangan yang direbus dan dimakan bersamaan dengan lontong dan sate kerang. Kuah pada makanan ini berasal dari petis dan sedikit perasan jeruk nipis. Biasanya jika memakan lontong kupang ini, untuk minumannya dipadukan dengan es degan.

\section{H. Nyadran}

Nyadran merupakan tradisi bersih desa yang biasa diadakan pada bulan purnama di bulan Ruwah kalender Jawa. Nyadran merupakan tradisi upacara adat bagi para nelayan kupang desa Balongbendo, yang merupakan tanda rasa syukur kepada Tuhan Yang Maha Esa. Salah satu kegiatan nyadran adalah berupa peragaan cara mengambil kupang di tengah laut selat Madura.

\section{Wayang Gagrak Sidoarjo}

Wayang kulit ini juga banyak disebut dengan wayang Jek Dong, yang dipercaya berkembang sejak awal abad 15. Cerita yang diambil berasa dari wayang purwa Jawa Tengah setelah penyebaran agama islam di Jawa. Wayang yang saya pilih yang menciri khaskan dari Sidoarjo adalah Prabu Boma Narakasura Tiwikrama. Menurut cerita, pada saat kandungan ibunya dimasuki Prabu Kebondanu dikarenakan Prabu Kebondanu dibunuh Bapaknya Prabu Boma pada saat dalam kandungan ibunya, jadi pada saat marah, Prabu Boma berubah wujud menjadi kerbau.

\section{V.IMPLEMENTASI DESAIN}

\section{A. Monumen Jayandaru Monumen Jayandaru (Jayandaru Bandeng Windhu)}

Ikan bandeng dan udang windhu merupakan hasil alam Sidoarjo yang paling banyak dan Jayandaru memiliki sebuah arti kekayaan. Diharapkan Sidoarjo terus berjaya dengan kekayan hasil alamnya.
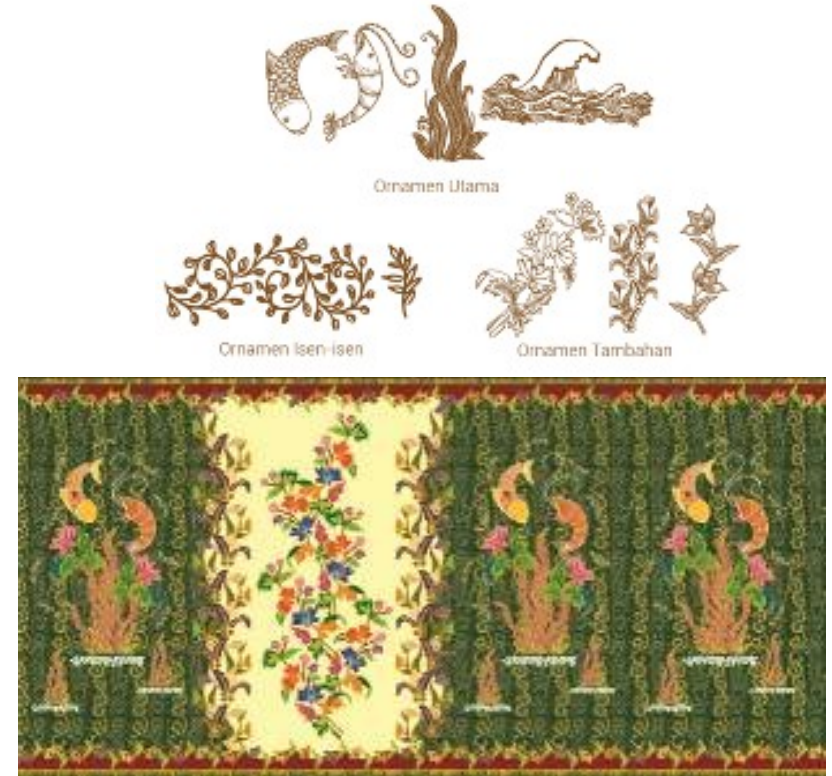

Gambar 7. Ornamen dan implementasi monument Jayandaru.

Sumber : Nautica, 2019

\section{B. Candi Pari (Pandelegan Pari)}

Sebuah tanda yang memiliki makna sebuah kemakmuran dan pari memiliki arti padi. Diharapkan Sidoarjo selalu makmur dengan hasil padi yang dihasilkan dari setiap daerah di kabupaten Sidoarjo.
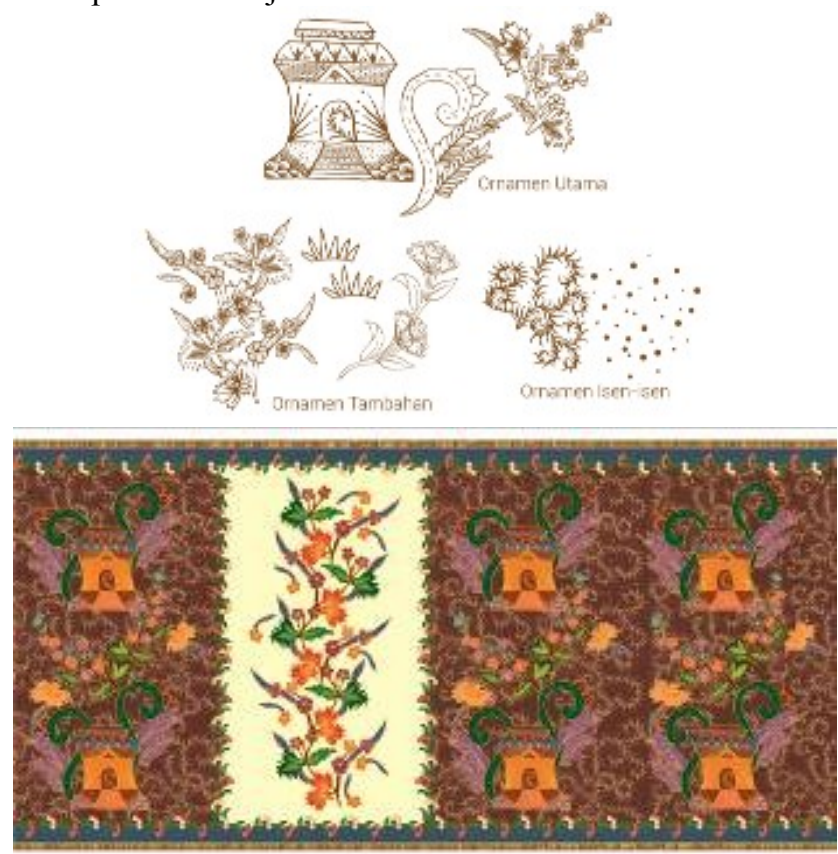

Gambar 8. Ornamen dan implementasi Candi Pari.

Sumber : Nautica, 2019

\section{B. Wayang Gagrak Sidoarjo (Bonaraka Tikma)}


Diambil dari salah satu lakon wayang dengan nama Prabu Boma Narakasura Tiwikrama yang memiliki sebuah kesaktian tidak akan mati dan selalu berusaha segenap tenaga. Diharapkan kabupaten Sidoarjo tidak akan mati dan terus berusaha segenap tenaga dan pikiran untuk menjadi lebih baik.
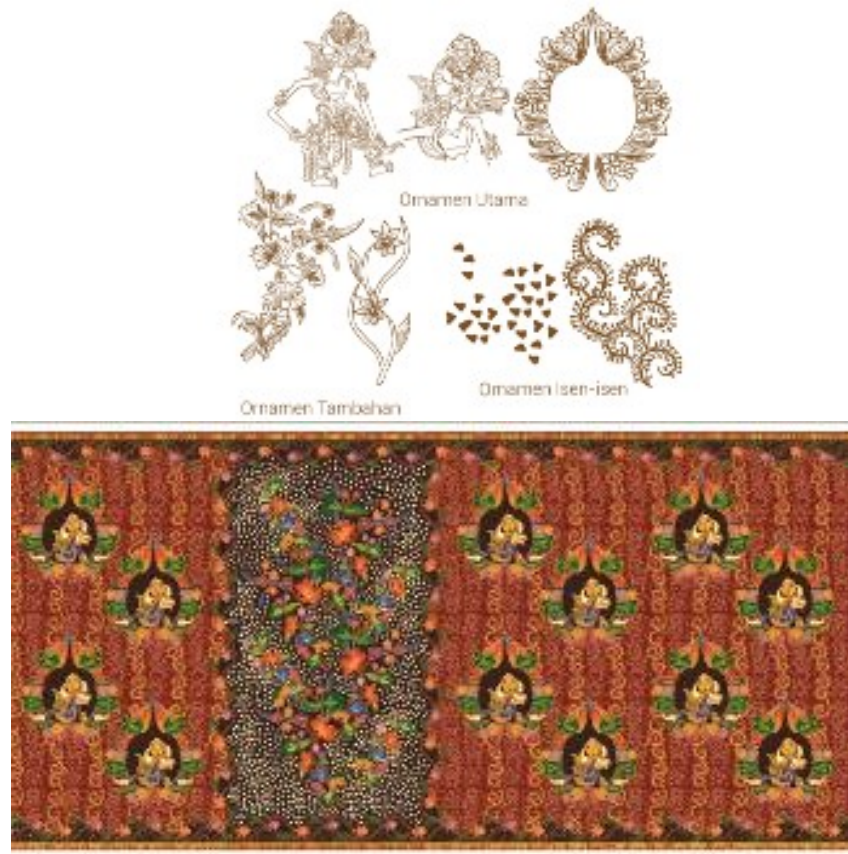

Gambar 9. Ornamen dan implementasi wayang gagrak.

Sumber : Nautica, 2019

\section{Nyadran (Layar Esung Bantala)}

Berasal dari kata berlayar yang mengartikan mengarungi lautan, sedangkan esung bantala berasal dari bahasa sansekerta yang memiliki arti esung dan tanah atau bumi. Makna dari nama tersebut berlayar mengarungi lautan untuk memberikan hasil bumi atas rasa syukur yang telah didapat.
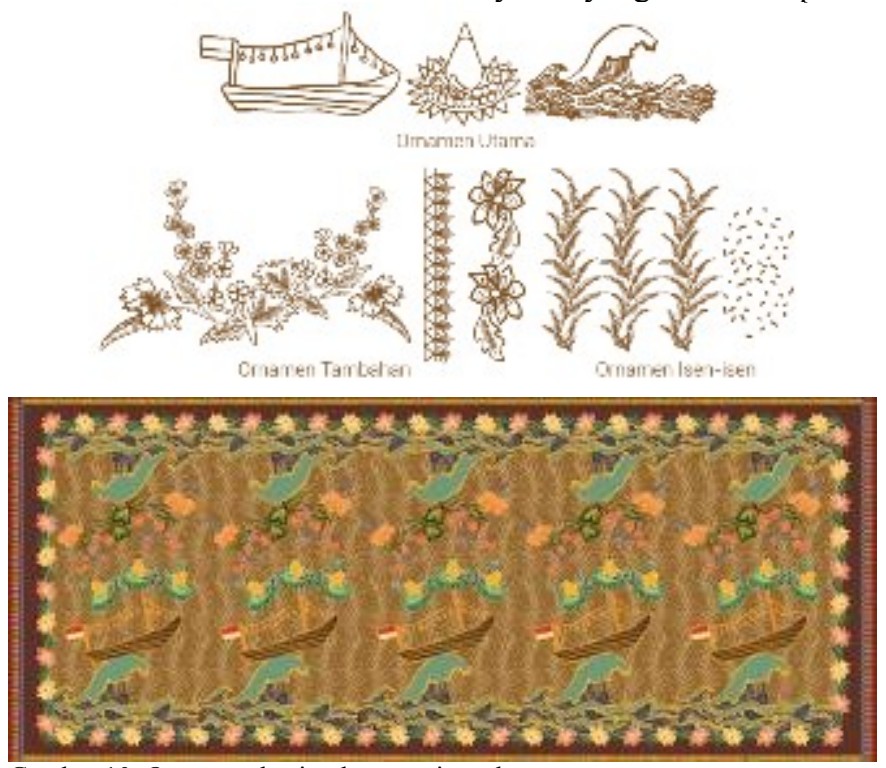

Gambar 10. Ornamen dan implementasi nyadran.

Sumber : Nautica, 2019

\section{Lontong Kupang (Kerang Alit)}

Kerang alit memiliki arti kerang kecil. Maksudnya adalah kuliner Sidoarjo yaitu lontong Kupang yang populer berasal dari hewan dengan nama Kupang yang direbus yang disandingkan dengan lontong dan sate kerang.
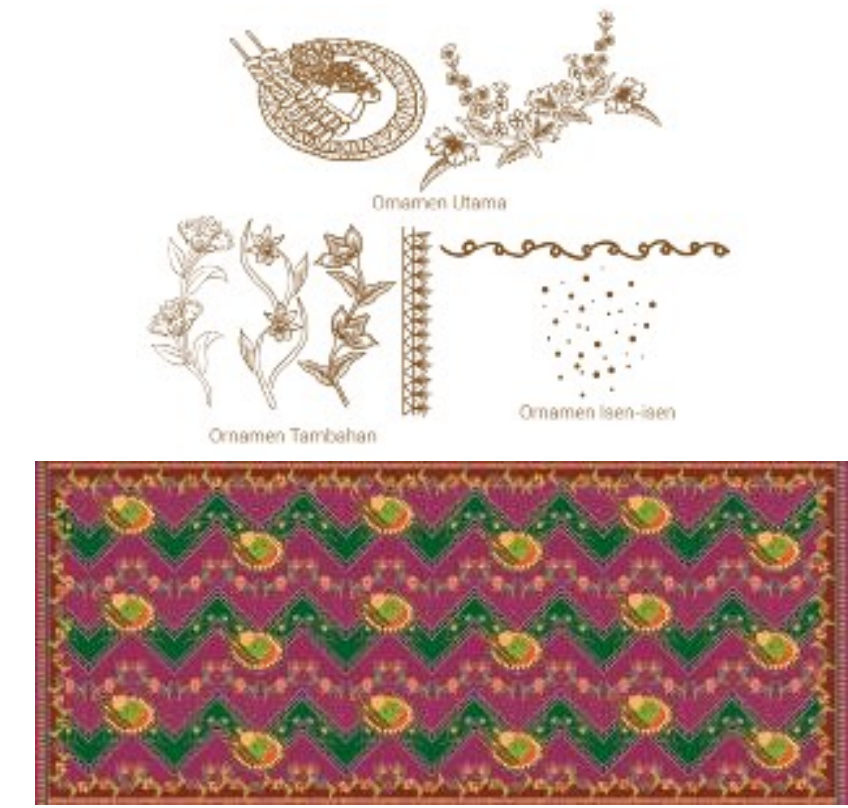

Gambar 11. Ornamen dan implementasi lontong kupang

Sumber : Nautica, 2019

\section{KESIMPULAN}

Pada perancangan motif batik ini merupakan salah satu cara untuk melestarikan dan memperkaya motif batik Sidoarjo. Perancangan motif batik ini menggunakan big idea pada perancangan ini adalah "The New Batik by the strength of Sidoarjo". Makna dari keywords tersebut dalah membuat desain motif batik baru yang berasal dari kekuatan dari Sidoarjo. Kekuatan tersebut berasal dari potensi daerah Sidoarjo. Perancangan ini ditujukan kepada pengerajin batik dan paguyuban batik Sidoarjo, supaya dapat memiliki ragam motif dan membuat hal baru. Diharapkan pula dapat ditujukan untuk pembaca yang ingin mempelajari mendesain motif batik.

Maka dapat ditarik pembelajaran bahwa dalam melakukan perancangan motif batik untuk Sarung batik dan Jarik dapat berasal dari mana saja, sama halnya kita dapat memvisualkan dari 5 potensi daerah kabupaten Sidoarjo seperti: Monumen Jayandaru, Candi Pari, Nyadran, Wayang Gagrak, dan lontong kupang, merupakan salah satu cara yang efektif dalam pembuatan motif batik untuk menunjukkan suatu daerah. Dan dalam pembuatan motif batif dapat dilihat melalui ukuran motif dan ketelatenan dari pengerajinnya.

\section{DAFTAR PUSTAKA}

[1] P. Alesti, "Perancangan Buku Visual Eksplorasi Motif Batik Jombangan," Surabaya, 2017.

[2] A. Santoso, "Perancangan Buku Visual Batik Tulis Tradisional Solo," Surabaya, 2010.

[3] M. Meilani, "Teori Warna: Penerapan Lingkaran Warna dalam Berbusana," journal.binus.ac.id, 2013. [Online]. Available: http://journal.binus.ac.id/index.php/Humaniora/article/view/3443. 
